Journal of Law \& Social Studies (JLSS)

Volume 2, Issue 2, pp 78-86, 2020

www.advancelrf.org

\title{
Death Penalty in Pakistan in nexus with International Human Rights Laws and Sharia'h
}

\author{
Muhammad Waqas Javed \\ Lecturer, School of Law \\ Quaid-e-Azam University, Islamabad. \\ Email: mwjaved@qau.edu.pk \\ Naila Kareem \\ Advocate High Court \\ Visiting Lecturer, Bahauddin Zakariya University, Multan. \\ Email: khiljinailakareem2307@gmail.com
}

\begin{abstract}
In the instant study, we focus to point out Islamic perspective in relation to international human rights laws pertaining to death penalty in the context of Pakistan. We have discussed the perspective certain jurists who claim qisas is an alternative prayer, and it can be abolished. However, the study maintains that Islamic injunctions support, and recommend for capital punishment for certain offences, while diyatis an alternative penalty. Further, we have deliberated death penalty in the light of human rights conventions with special focus on Article 6 of the International Covenant of Civil and Political Rights (ICCPR), 1966. The debate also surrounds abolitionists or retentionists views with special reference to Pakistan. It concludes that immediate abolishment of death penalty may not be possible in Pakistan. Nevertheless, as a first step, it needs to re-interpret the phrase "most serious crimes" envisaged under Article 6 of ICCPR in its true letter and spirit, or to exercise de facto abolishment of it until its crippled criminal justice system ensures international fair trial standards. As internal peace and security situation improves in Pakistan, so it may enforce de-jure halt.
\end{abstract}

\section{Introduction}

In Pakistan, imposition of death penalty is a valid way of punishment. International community calls for abolishment of it. However, Islam recommends such mode of punishment for various nature of offences. Pakistan's state religion is Islam; no law can be against Islamic injunctions, and any such law shall be declared null and void under Articles 227 and 203-D of the Constitution of Pakistan 1973.The punishment is not only enforceable in Pakistan, but also many countries like United States of America USA, China, Iran, Japan, Saudi Arabia and other have laws which prescribe death penalty for many offences. In contrast, many states of the world have put a ban on death penalty branding it as an inhuman, cruel and against human dignity of man (Ali et al., 2015).

Under Section 55 of Pakistan Penal Code (PPC), 1860, death penalty is provided as a mode of punishment. Under Section 368 of Criminal Procedure Code (Cr.PC), 1898, the mode of execution of death sentence is that the person on death row shall be hanged till death. Article 9 of Constitution protects right of life, but it is subject to law. The exception creates concession for capital punishment. In Shahla Zia case, it was held right of life is not a mere right to live vegetative or animal life rather it must be lived with human dignity and respect. It encompasses all the facets of human being (Pakistan Law Digest, 1994).

Human rights activists consider death penalty against human dignity and respect. Under their pressure, Pakistan observed de facto abolishment of death sentence as no offender was executed to death during the period between 2008 to 2013. Butthe temporary ban on death penalty was uplifted in 2014(Death Penalty Database, 2019), in the aftermath of vicious terrorists 'attack taking lives of innocent children in Army Public School, Peshawar. 
In continuance, around 507 of executions were conducted in Pakistan during 2014 to 2019 (Death Penalty Database, 2019). Huge number of execution are due to many reasons; one of it is that like many counties, Pakistan interprets the phrase "most serious crimes", enumerated in Article 6 International Covenant on Civil and Political Rights (ICCPR) 1966, in a very exhaustive way. Although the said provision of ICCPR protects right of life yet the threshold of "most serious" crimes" have not completely banned death penalty except death penalty for juveniles. Similar provision of Convention on Child Rights (CRC), 1989entirely bans infliction of such penalty on juveniles. Complete ban policy has also been adopted in Pakistan's domestic laws, but violations have also been reported.

Internationally and nationally, Pakistan has asked been to reconsider the provisions of its penal laws and at least keep the penalty only for most serious offences (European Commission Report, 2020).Despite ICCPR does not directly ban death penalty, but in case human guarantees and rights mentioned the Convention are violated and death penalty is imposed, such a penalty shall be unlawful and be against the object of ICCPR. In 1989, most of the states realizing nature of death penalty as cruel and gruesome, issued Optional Protocol II on ICCPR pertaining to abolishment of it. Despite eighty-eight states are party and forty states are signatory to it (United Nations Treaty Collection, 2020), but there are numerous states which recognize death penalty creating divide. Pakistan still is not a party to it.

There are two approaches as to death penalty i.e. abolitionists vs. retentionists approaches. Abolitionists are those who argue against the enforcement of death penalty. On the other hand, retentionists demands for retaining the death penalty as punishment. Despite temporary halt on death penalty between 2008-2013, Pakistan falls within the category of retentionists. The reasons for such posture of her may lie into its social and economic conditions, unfathomable terrorists' activities after $9 / 11$ and war on terror, orthodox nature of state and its constitutional structure. Opponents have criticized it; they maintain Pakistan Criminal Justice System is not meeting with the international standards of fair trial, mostly destitute citizens become prey for such inhuman castigations. Among other concerns, death penalty in Pakistan may cause double jeopardy for the convicts.

It may be challenging at this point in time to abolish death penalty in Pakistan, nonetheless it isurged at least to restrict the exhaustive interpretation of "the most serious crimes" or abolish it in future as criminal justice system of Pakistan is lacking fair trial standards.

\subsection{Objectives of the Study}

- To point out Islamic perspective in nexus with International community perspective on death penalty.

- $\quad$ To elaborate the current debate among abolitionists or retentionists of death penalty.

- To determine Pakistan's perspective on death penalty and what should be its future measures either to retain or abolish death penalty?

- To explore "life expectancy" nexus with death penalty in the light of principle of double jeopardy.

\subsection{Research Questions}

i. What is the Islamic perspective about death penalty?

ii. Whether Qisas is alternative punishment to Diyat or vice versa?

iii. What is the international human rights stance pertaining to capital penalty?

iv. In Pakistan, what are the major factors or causes of capital punishments, and their critical analysis in the light of abolitionists Vs. retentionists approaches?

v. How come "life expectancy" got nexus with death penalty and principle of double jeopardy in the light of judgments of Supreme Court of Pakistan?

vi. What is the status of capital penalties imposed on juveniles in Pakistan?

\section{Death Penalty in Islam}

2.1. Protection of Life as Sharia's Objective

There are five objectives of sharia in Islam;these includesHifz ul Iman (protection of belief), Hifz ul Jan (protection of life), Hifz ul Nasal (protection of hereditary), Hifz ul Aqal (protection of intellect) and Hifz ulMaal(protection of property) (Rehman, 2009).Protection of life, Hifz ul Jaanis one the foremost objective of it. Allah has regarded man as his Khalifah on earth; Regarded humans as best among all the creatures. For this reason,He has not permitted a man to kill another while taking the law in hands; It would be sheer injustice to allow anyone to do so.Rather, Islam believesit is a sole prerogative of Him to bestow or take life.(Mumisa, 2015).

\subsection{Debate about death penalty in Islam}

It is ordained in Quran, whosoever kills a person, it is like he killed to the whole humanity. Whosoever saves a life, it is like he saved to the whole mankind. In Surah Al Maidah, verse No.32 and 33 it is stated, "If anyone slays a person, 
it would be as if he slew the whole people: and if anyone saved a life, it would be as if he saved the life of the whole people". Similarly, in V. 178 of Surah Baqrah, Allah Almighty further mentions about the punishment for offence of murder;

("O you who believe! Al-Qisas (the Law of Equality in punishment) is prescribed for you in case of murder: the free for the free, the slave for the slave, and the female for the female. But if the killer is forgiven by the brother (or the relatives) of the killed against blood money, then adhering to it with fairness and payment of the blood money to the heir should be made in fairness.

This is an alleviation and a mercy from your Lord. So, after this whoever transgresses the limits (i.e. kills the killer after taking the blood money), he shall have a painful torment")

\subsubsection{No discrimination on infliction of capital punishment in Islam}

Among pre-Islamic Arabs, it was a tradition among tribes that they determined the value of life according to the status of killed deceased; they were used to kill similar status person or huge amount of low status humans as a punishment for murder in retribution. It means life of a slave was not equal to life of honorable and free man. Similarly, life of female was not equal to life of a man. The last-mentioned verse of Holy Quran was revealed to end this brutal custom among Arabs. Under this verse, penalty of qisasor diyatis recommended by taking life only of the killer.It ended the gruesome practice of taking lives of innocent humans other than the murderer himself (Al-Madudi).

In the next verse No. 179 of the same above given chapter of Holy Quran, it is said that in the capital punishment there is life for you. It means when you impose capital punishment, it would bring peace and tranquility in the society as it will decrease the unlawful killing i.e. extra-judicial murders. It states as "And there is (a saving of) life for you in AlQisas (the Law of Equality in punishment), O men of understanding, that you may become Al-Muttaqoon (the pious)" (Mauddudi).

\subsubsection{Right of life is indispensable except under due process of law}

No one can unlawfully take life of anyone. If an accused has committed any offence, he must not be killed, in retaliation rather there must be proper trial against him in the court of law. It may punish the offender if proven to be guilty. In case hostility with any other state or nation, no individual himself can kill a citizen of such state on commission of any offence, it shall still be sole prerogative of court of law to decide the matter. Similarly, killing any other person, as a revolt, is not permitted even for any evil or corruption committed in the earth. This amounts to extrajudicial killing. Islam totally bars it.(Al-Madudi, 1995). The world "soul" has been used in Quran to show importance of human life. It has not been ordained that "life or soul of Muslims" should not be taken without process of law. Rather it only soul is used. Therefore, the life of non-Muslims is as scared as life of Muslim.

Hadith of Holy Prophet (PBUH) also stipulates for punishment of death. From various hadiths, it is a proven fact that capital punishment is enforceable in Islam. And once the Prophet (peace and blessings of Allah be upon him) said: "It is not permissible (to shed) the blood of a Muslim who bears witness that there is no god but Allah and that I am the Messenger of Allah, except in three cases: a married adulterer, a soul for a soul, or one who leaves the religion and splits from the jamaa'ah." (Al-Bukhaari, 6484).From the Hadith in nexus the above-mentioned verses of Holy Quran, one thing is crystal clear that extra-judicial killing in Islam is not permissible at all.

However, Islam considers death penalty imposed, in due process of law, as a valid mode of penalty. In compliance of Quran and Sunnah, many Islamic states consider it as a valid way of sentence. Their method of executing capital punishment may vary, but they all almost enforceit while considering it as an element of Islamic law (Schabas,2000).

\subsection{Qisasor alternative punishment,Diyat}

Another significant question is whether death penalty can be abolished in Islam while considering it to be an alternative punishment to diyat?Many jurists and human rights organizations claim that Quran in addition to death penalty also provides for punishment of diyat, the blood money if the legal heirs compound the offence. It means forgiveness is given more credit as compare to revenge. In support of claim, a verse of Holy Quran is quoted which states;

("And We ordained for them therein a life for a life, an eye for an eye, a nose for a nose, an ear for an ear, a tooth for a tooth, and for wounds is legal retribution. But whoever gives [up his right as] charity, it is an expiation for him. And whoever does not judge by what Allah has revealed - then it is those who are the wrongdoers (Quran 5:45).”) 
Although the first part of the verse ordains for execution of qisas, tit for tat type of punishment according to severity of offence, upon the offenders. However, the second part of the verse provides a proviso for general rule of the verse. In the light of exception offered, it can be interpreted that Islam gives more worth to forgiveness. For two reasons, death penalty can be abolished under Islamic Injunctions. First, Quran itself gives alternative punishment of diyat against qisas. Secondly, Allah also recommends forgiving up right as charity (Penal Reform International, 2015).

Arguments advanced are misleading for factors; First, it ignores traditions of Holy Prophet PBUH which described death penalty for various offences. Secondly, it neglects the supra verse No. 179 of Surah Bakrah in which Allah SWT ordains that there will be life for you in Qisas. Allah recommends qisas to be enforced rather than diyat. Meanwhile, alternative punishment, diyat can also be given as per Holy Quran if the victim himself or all his legal heirs compound or waive the offence. So, alternative punishment is diyat rather than qisas as compounding of the victim or legal heirs is indispensable for awarding sentence of diyat. The court of law or state cannot abolish death penalty itself under Islamic injunctions.

\subsection{Other Offences for which Haddpunishment shall be imposed}

There are five kinds of offences which punishable with hadd, means broader or wider. These include drinking, theft, imposition of false allegation of unchastity, Zina bil Raza, Hiraba \& Fasad fil Arz. There is conflict among the Islamic jurists as to number of offences for which had may lie. Some are of the view, drinking and apostasy are not in the list of five as punishment for such offences as hadd is not given in Quran and Sunnah. The list of such offences was extended by Imams Shafi (RA) and Imam Malik (RA). They included offences of revolt and apostasy among offences on which had would be imposed. Therefore, there is no agreement between the Islamic scholars as to what offences are punishable with hadd. (Sohail\& Mahmood, 2019).

\subsection{Principle of Fisad-fil-Arz and Capital Punishment}

The scope of Fisad-fil-Arz is wide-ranging; In case an act or offence violates any of the objectives of Islam, such an act qualifies as a mischief or corruption on the earth. (Sohail\& Mahmood, 2019).It is more reinforces from the fact that in case of grievous or heinous offences, punishment of tazir, a discretionary punishment, may also be inflicted in addition to qisas.It also implies qisas is not an alternative punishment rather a recommended and valid form of penalty. Islam prescribes it as form of punishment for various kind of offences; the scope of which has even extended tofisadfil-Arz.Jurists are of the view that any offence committed against the objectives of Islam shall fall within the category of fisad fil Arz for which the haddmay be imposed. (Sohail\& Mehmood, 2019)

\section{Death Penalty \& International Law}

The first and foremost step towards the restriction of the death penalty was taken by introduction of Article 6 in ICCPR. It gives a threshold of "most serious crimes" for imposition of death penalty. The right of life has clearly been given certain protection, but it has not completely banned death penalty. Further, same provision of ICCPR prohibits execution of death sentence upon the juveniles and pregnant women. (Gino J. Naldi, 2009). However, it was certainly a first endeavor to limit death punishment merely for the most serious nature of offences by the world community. Earlier, there was no such restriction on exercise of it. Indeed, it would not be wrong to assert that it was a first step towards abolition of the death penalty. However, the phrase "most serious offences" has been widely misused by many states.

Only Pakistan has at least twenty-seven offences which are punishable with capital punishment. Consequently, it may not be wrong that international community have consensus on abolition of it or at least to settle the list of offences falling within the category of the "most serious offences". Non defining of the phrase has given liberty to states interpreting it in an exhaustive manner even for numerous petty or non-serious offences.

As per opinion General Recommendation 22 of the Human Rights Committee (HRC) death penalty is in no way completely banned under supra provision of the ICCPR. Nevertheless, in case a state is unable to ensure other basic rights envisaged in the ICCPR, it shall be unlawful to impose death penalty. For instance, when right of fair trial was not available to the accused person, imposition of death penalty on such accused shall be deemed in violation right of life under Article 6 of ICCPR. This implied prohibition regime was further reinforced through Optional Protocol(OP) II of ICCPR. (Gino J. Naldi, 2009)Article 1 of OP-II to ICCPR states "Each State Party shall take all necessary measures to abolish the death penalty within its jurisdiction"

Under Article 6(5) of ICCPR and under Article 37 (a) of Convention on Child Rights (CRC), 1989 call for ban on inflicting death penalty on any child under the age of eighteen years at the time of commission of offence by him. Infliction of death punishment on juvenile has almost become a universal practice of states. 


\section{Pakistan and Capital Punishment}

Pakistan has declared Islam as its religion in its Constitution. Following Islamic injunctions Pakistan has also maintained death penalty as valid mode of punishment in its penal laws. Section 55 of PPC defines punishment.It envisages death penalty as one of a kind of penalty. (Ali et. al., 2015) Even one of the leaders and Ex-Prime Minister of Pakistan, Zulifqar Ali Bhutto was hanged till death in 1979. This shows how frequently Pakistani courts have imposed this kind of punishment. For an exhaustive list of twenty-seven offences, death penalty is punishable. These offences include murder, high treason, rape, blasphemy, high-jacking and many other. Further, it is a common belief among Pakistani community that death penalty is more effective kind of penalty having deterrence value among people having possible imminent killers. Meanwhile, its social and economic conditions require to keep check on unlawful killings (Makhdoom, 2014), apart from prevailing terrorists and extremist activities in Pakistan.

\subsection{Constitutional safeguard for capital punishment in Pakistan}

Significantly, under Article 9 of Constitution of Pakistan, 1973, no one can take life of another. However, it creates an exception to the general principle. It provides, "No person shall be deprived of life or liberty save in accordance with law". Under this provision, it is allowed for state to impose death penalty as a valid penalty while following due process of law and procedure laid down .Further right of life has been explained by Karachi High Court in its judgment that the word life envisaged in Article 9 of the Constitution of Pakistan 1973 has a very wide scope. It circumscribes all the rights significant for a quality living with human respect and dignity. It cannot only be attributed to a life i.e. animals or vegetative life (PLD, 2017). Reliance can also be placed on Shahla Zia Case (PLD, 1994).

In addition, Pakistan follows Islam its religion. Under Article 227, no law can be enacted against Islam. It is incumbent that all laws must not be in conflict of the Islamic injunctions. Clause 1 of it states as "All existing laws shall be brought in conformity with the Injunctions of Islam as laid down in the Holy Quran and Sunnah, in this Part referred to as the Injunctions of Islam, and no law shall be enacted which is repugnant to such injunctions." This view has been further supported by Article 203-D which provides that any law made against Islamic principles shall be struck down by Federal Shariat Court of Pakistan. In presence of two-fold provisions of Constitution, it may be difficult to end up death penalty in Pakistan. As discussed in the last section that Islam allows capital punishment to be imposed and it would be against Islamic injunctions if capital punishment shall be abolished.

\subsection{After 9/11 Socio-economic and terrorism circumstances in Pakistan and Death penalty}

After 9 September 2001 attacks, Pakistan became an ally of United States of America (USA) in war on terror which has drastically affected the lives of people in Pakistan. Around seventy thousand innocent people died in various terrorists' attacks and hundreds of thousands got heinously injured and became disabled, not to say about the financial loss state of Pakistan suffered. In the light of prevailing circumstances, it must be difficult for state of Pakistan to abolish death penalty. It is argued that Pakistan remained under continuous war. This why death penalty should not be abolished.

Countries like Pakistan facing on going issues i.e. terrorism, extremism and enhancing crimes in their societies have been demanded by United Nations, time and again, to ban the death penalty while it has failed to provide any practical replacement of death penalty (Sikandar Shaheen, 2012).

\subsection{Temporary Halt on Death Penalty in Pakistan}

Contrary to practices, drastic change in policy of Pakistan pertaining to death penalty was made during period between 2008 to 2013, then Government of Pakistan imposed halt on executions of death penalties. It can be said Pakistan observed de facto ban on it. Voices at national or international level were soaring that Pakistan would implement de jure abolishment of it. However, it was a temporary arrangement as in 2014, this interim ban was uplifted. In the upcoming next five years, massive death sentences were executed by Pakistan. Around five hundred and seven convicts on death row were executed. (Death Penalty Database, 2019). The change in policy was a result of terrorist's attacks on innocent citizens including educational institutions i.e. schools etc., and other public places.

In the next year 2015, around at least 150 death sentences were executed in Pakistan (Amnesty International, 2015). This indicates trend towards imposition of death penalty upon culprits of heinous crimes was once again.

\subsection{Concerns about lack of Fair Trial Principles' Practice in Pakistan in nexus to capital penalty}


To the contrary, Pakistan Criminal Justice System was inherited from British Colonial System and it has not been much evolved after attaining its liberation. Many a times, amendments or new laws were enacted to give stronghold to the monarch's regimes which lead to human rights violation. (Crisisgroup.org, 2010). This policy of human rights infringements may continue as a trend setter. In 2019, the Courts of Pakistan have convicted around 638 persons, and fourteen convicts were executed. The main concern about these sentences is that proceedings in courts in which death sentences were imposed do not match to the international standards of fair trial (Amnesty International, 2019). Such kind of punishments have adverse impacts due to grey areas in policies and judicial systems, resulting miscarriage of justice. Any death sentence without offering right of fair trial need to be commuted. Similar view has been expressed by Human rights General Comments No. 22. Implying HRC comment, there is no doubt to regard these death penalties in Pakistan as in clear violation of Article 6 of ICCPR.

\subsection{Deterrence; for and against arguments}

It is common belief of supporters of capital punishment, it creates deterrence in the mind of any future imminent offender or killer. When a person hears or sees about execution of death penalty upon convicts of heinous offences like of murder, fear is created in their sub consciences. They may even not dare to think for commission any offence. This view is widely prevalent in Pakistan among the masses.(Makhdoom, 2014). It is a notion, crimes and criminals must be tackled with "iron fist" to suppress the commission of offences and it will bring peace in the society.

However, deterrence argument is highly over-regarded, and much hype of it has been created in the society of Pakistan. Use of capital punishment has not instilled progression in public law \& order and tranquility. Similar view has also been expressed by Human Right Commission of Pakistan (HRCP). It is strange to express that Pakistan is one of the countries to impose huge number of executions of death penalties but keeping peace and maintaining order in the society is still in a quagmire. The "iron fist" doctrine is itself imperfect and unfair (International Federation of Human Rights Report, 2007). It is imperative to ban death penalty for betterment of society as it may trigger much harm in the society by risking the lives of the innocents. Mostly, weak, and underprivileged are become a hunt of death penalty. Various international reports of United Nations (UNs) reveal that deterrence aspect of capital punishment has got no sound footing. Merely, keeping it intact under public pressure, it would a gross injustice.(Ali et al., 2015). Once a life taken, it would never be compensated as capital punishment is irrevocable. It prohibits the correction of mistakes by the justice system and leaves no room for human error, with the gravest of consequences. There is no evidence of a deterrent effect of the death penalty (United Nations, 2015). Both arguments for and against are significant in context of Pakistan. On one hand, prevailing situation may demand for imposition of death penalty in Pakistan. On the other side, if we see weaknesses of our Criminal Justice System argument, it would not be wrong to say that poor and weak are more likely to be convicted for such a cruel or degrading punishment.

Further, countries which are under their political evolution process from dictatorship to democracy, they may take more time for completion of such a process and then these states are more likely to ban such punishments. This is evident from the fact that many states which completed this process after the second World War, they had banned capital punishment, subject to certain exceptions (Futamura, \&BernazEdt, 2014). USA is a prime instance of such an exception. Pakistan is also one the state that is under political transition, it may in future abolish death penalty. But it seems to be difficult for two reasons.

First, Pakistan is state with an orthodox ideology. Any secular or modern state may amend the law with much ease, but it is not the case with Pakistan. It builds public pressure on respective Governments in Pakistan to maintain the law unbothered. Secondly, despite ignoring or changing the mind set of people, constitutional and institutional structure of Pakistanis also an impediment for the change in the law. However, it is recommended to abolish it (Makhdom, 2014). The second reason is not much significant as it is easy to amend law or constitution when such new law or amendment aspires the will of the people of land.

\subsection{Delay in trial, Death penalty and double jeopardy}

Another issue pertaining to death sentences in Pakistan is that the convicts suffer rigors of years and years of imprisonment during pendency of trial, or remedies against their convictions due to weaknesses or lapses in Criminal Justice system (Editorial, Tribune, 2018), (Asad, 2020). In most of the cases, convicts, during the pendency of trial or appeals, imprisoned for a period spanning to life imprisonment. This means such persons have served the period of life expectancy in jail which itself a kind of punishment. If such accused or convicts are then hanged till death. This may amount to double jeopardyi.e. "no one should be punished twice". 
This principle was upheld by Supreme Court of Pakistan in Dilawar Hussain Vs. The State. It was held that once the accused person has served imprisonment of life expectancy during the pendency of his case, imposition of death penalty on such an offender attracts the principle of double jeopardy envisaged in Article 13 (a) of the Constitution and Section 403 of Cr.PC. Reliance can also be placed on another case Hasan and others Vs. The State. These cases are instances of remedial and curative justice.

However, Supreme Court of Pakistan, full bench, reviewed its earlier decisions of supra both cases in Khild Iqbal and others Vs. Mirza Khan and others. The issue before the court was again that whether or not maintaining death penalty of convict who served full life expectancy in prison equivalent to life imprisonment during pendency of his legal remedy available against his guilty verdict amounts to double jeopardy? It was held that principle of double jeopardy did not lie as there was no new trial of the convict rather, he was exercising a remedy against his conviction which was pending. Meanwhile, Section 403 of Cr.PC attracts when new trial is initiated; therefore, such proceedings against conviction did not fall within the ambit of new trial. However, it was held that death penalty could be commuted to life imprisonment, but it shall not be sole ground of it.

\subsection{Death Penalty and Juvenile}

Pakistan has ratified Convention Child Rights (CRC) and ICCPR in 2010. Both conventions require that no juvenile who was under the age of eighteen at the time of commission of offence shall be punished with death penalty. In compliance of CRC Pakistan promulgated Juvenile Justice System Ordinance (JJSO), 2000 which was later replaced with Juvenile Justice System Act (JJSA), 2018. Under JJSA, it is prohibited the execution of capital punishment on juveniles.

The problem with JJSO was that it was not given retrospective effect regarding prohibition on execution of death penalty on juveniles. It was under the international pressure, the then President of Pakistan Mushraf issued a notification to stop the execution of death penalties against juveniles on death row. However, there are still many cases wherein convicts are waiting for execution of their death penalty despite they were being juvenile at the time of commission of the offence. Many of the juvenile offenders were even executed. This is due to retrospective effect was not given to the law. Further, many offenders could not take this ground at the time of the trial or their lawyer did not ask for their age or such offenders were even ignorant about their age. Resultantly, many of the juveniles were hanged in Pakistan in a blatant violation of her obligations under JJSO and International Law (Justice Project Pakistan, 2015). Similar kind of issues have also been suffered by mentally retarded or disable persons in Pakistan.

\section{Conclusion}

International community calls for abolishment of death penalty in Pakistan. Although under Article 6 of ICCPR a threshold of "most serious offences' has been given, it has been misused by many states including Pakistan while extending the application of the phrase even to petty offences. As per Human Right Committee, Article 6 of ICCPR itself does not bar death penalty. Nevertheless, in case other rights are violated about Article 6,i.e. a country does not fulfil the criteria of fair trial, such a death conviction would violate this provision of ICCPR. Implying the interpretation of HRC, Pakistan maintaining death penalty with its weak implementation of fair trail rights, and crippled criminal justice system is a matter of great concern for international community. Internationally, total ban on death penalty was introduced through OP-II on ICCPR, but Pakistan is not a party to it.

As far as Islam is concerned, it allows death penalty for the convicts for a few kinds of offences. Qisas is not an alternative punishment for diyat rather it is a recommended penalty under Islamic injunctions. Pakistan is an Islamic state, and no law can be made against Islamic injunctions. Any such existing law shall be declared void. Penal laws of Pakistan have been maintained in accordance with the Islamic standards. Rather, Pakistan has extended application of capital punishment to an extended list of twenty-seven offences. This extension has been made under the principle of fasad-fi-Arz. Despite Islam urges to enforce capital punishment, but in no way, it may allow any punishment for innocents who have even not been provided with fair trial opportunities.

Apart from orthodox nature of state, due to many other factors Pakistan has kept death penalty intact, except brief $d e$ facto suspension between 2008-13. These reasons include prevailing terrorism attacks in the after math of 9/11, increasing crime rates and constitutional structure of Pakistan. However, the opponents contend that Pakistan has executed hundreds of thousand convicts for death penalty, but this has not brought any beacon of tranquility in society. Under pressure of these voices, Pakistan has reduced the number of executions to fourteen in 2019 as compare to number exceeding 150 in 2014.Nevertheless, Pakistan is in a transitional process from monarchy to democracy. Unless the process completes, Pakistan may permanently ban death penalty. Until then, there may not be possibility in Pakistan to change its retentionists character. Nevertheless, Pakistan has banned execution of death penalty on 
juveniles in fulfilment of its obligations under ICCPR and CRC. It enacted JJSO, 2000 and later replaced with JJSA, 2018. However, juveniles' rights have also been repeatedly violated. Grey areas lie with old cases as JJSO was not given retrospective effect. Resultantly, violations have also been reported due to age determination issues. Similar is the situation for mentally retarded and disable persons. Among other concerns, it was held by Supreme Court of Pakistan in supra two cases namely Dilawar Hussancase and Hasan and others case, execution of death penalty or convict's imprisonment for a period equal to "life expectancy" during pendency may cause double punishment of the convicts. As a sole ground, in such cases, convictions of death sentences were commuted. However, the Supreme Court in Khalid Iqbal, full bench case, did not consider it as sole ground for commutation of death penalty.

At this juncture, completely abolishing capital penalty may be a quagmire for Pakistan; nonetheless, it is recommended to initially restrict the exhaustive list of offences punishable with death penalty under its penal laws while properly interpretating phrase "the most serious crimes" under Article 6 of ICCPR, or to impose de-facto ban on it as criminal justice system of Pakistan lacks fair trial principles' standards. As law and order situations improves in Pakistan, it may impose de jure ban on it.

\section{References}

Ali, et. al., (2015), Abolition of Death Penalty (Case Study of Pakistan), MAGNT Research Report, Vol.3 (3). PP: 245-251.

Amnesty International (2015), Death Penalty 2015: The good and the Bad, available at https://www.amnesty.org/en/latest/campaigns/2015/07/death-penalty-2015-the-good-and-the-bad/

Amnesty International 2019, Death penalty in 2019: Facts and figures, available at https://www.amnesty.org/en/latest/news/2020/04/death-penalty-in-2019-facts-and-figures/

Death Penalty Database (2011), https://www.deathpenaltyworldwide.org/country-search-post.cfm?country=Pakistan dated 27-11-19.

Dilawar Hussain v. The State 2013 SCMR 1582

European Commission (2020), The EU Special Incentive Arrangement for Sustainable Development and Good Governance ('GSP+') assessment of Pakistan covering the period 2018 - 2019, available at https://op.europa.eu/en/publication-detail/-/publication/e01fc63a-5327-11ea-aece-01aa75ed71a1/languageen accessed on 10-08-2020

Rehman, Fazal (2009), Major themes of the Quran: Second Edition (University of Chicago Press, 2009).

Gino J. Naldi (2009), The prohibition on death penalty in International Law, Cambridge University Press.

Hasan and others v. The State (2013), PLD, SC, 793.

Imad Hussain Vs. Govt of Sindh (2007), PLD Kar. 116.

International Crisis Group (2010), Reforming Criminal Justice System of Pakistan, Asia Reports, accessed on 23-082020 from https://www.crisisgroup.org/asia/south-asia/pakistan/reforming-pakistan-s criminal-justicesystem

IFHR and HRCP (2007), Slow march to the gallows Death Penalty in Pakistan Report.

Justice Project Pakistan (2015), “Juveniles on Pakistan's Death Row" available at https://tbinternet.ohchr.org/Treaties/CRC/Shared\%20Documents/PAK/INT_CRC_NGO_PAK_21444_E.pd f accessed on 03-12-2020.

Khild Iqbal and others Vs. Mirza Khan and others (2015),Pakistan Law Digest,SC, 50.

MadokaFutamura, Nadia BernazEdt. (2014), The Politics of the Death Penalty in Countries in Transition, Routledge. 
Asad, Malik (2020), IHC lambastes criminal justice system, The Dawn available at https://www.dawn.com/news/1554636.

Mumisa, Michael (2015), "Sharia law and the death penalty: Would abolition of the death penalty be unfaithful to the message of Islam?", Penal Reforms International available at https://cdn.penalreform.org/wpcontent/uploads/2015/07/Sharia-law-and-the-death-penalty.pdf last accessed 28-11-2020.

Al-Madudi, Syed Abu (1995), Human Rights in Islam, p. 6 accessed from https://archive.org/stream/MaulanaMaududiHumanRightsInIslam/Maulana_Maududi_Human_Rights_in_Is lam_djvu.txt

Penal Reforms International (2015), Sharia law and the death penalty: Would abolition of the death penalty be unfaithful to the message of Islam? Available at https://cdn.penalreform.org/wpcontent/uploads/2015/07/Sharia-law-and-the-death-penalty.pdf accessed on 28-11-2020.

Shehla Zia Vs WAPDA (1994), Pakistan Law Digest, Supreme Court, 693.

Sikandar Shaheen, (2012) "Can Pakistan afford death penalty", retrieved from https://nation.com.pk/22-Nov2012/can-pakistan-afford-to-abolish-death-penalty date 20-11-2019.

Sohail\& Mehmood (2019), Islamic Criminal Jurisprudence on the Offence of Trafficking in Persons: An Interpretation of Fasad fil Arz and Hadd Offence, Vol. 20, Issue 2_11.

Al-Madudi, Syed Abu, Tafheem ul Quran, available at https://ahlesunnatpak.com/quran/tafheem_quran last accessed on 26-11-2020

The Express Tribune (2018), Editorial: A crippled justice system available at https://tribune.com.pk/story/1715621/crippled-justice-system-2 02-12-2020

Makhdoom,Tipu Salman (2014), Can legal fiction overcome religious and constitutional locks? Death penalty: a Pakistani perspective, Available

SSRN: $\underline{\text { https://ssrn.com/abstract=2617617 }}$ or http://dx.doi.org/10.2139/ssrn.2617617

United Nations (2015), “Moving Away from the Death Penalty: Arguments, Trends and Perspectives”, United Nation Publications

Schabas, William A. (2000), Islam and the Death Penalty, Wm. \& Mary Bill Rts. J. Vol 9, issue 1, p 223. 